\title{
ADVANBTAGES AND DISADVANTAGES OF GLOBALIZATION
}

\author{
V. R. CHAVAN
}

\section{S.M. College Kelapur (Pandharkawada)}

\section{INTRODUCTION:}

The concept of global village is very much found in ancient writings in India. The idea of Vashudhaiv Kutumbkam' i.e. whole world is like a family, is one of the examples of it. Now the process of globalization has spread up just like wildfire in the entire world. This process has its effects on the environment, on culture, on political system, on economic development and prosperity and on human physical wellbeing in societies around the world. So, the world is categorized in undeveloped or poor, developing and developed country. And the three main institutions like IMF, the world Band, and W.T.O. started governing the whole process of globalization. The real trust to the process of globalization was provided by the new economic policy introduced by the government of India in July 1991 at the behest of IMF and the World Bank.

\section{Concept of Globalization}

The term Globalization' has been widely used in 1960 in the Western world and in India 1990. It is a controversial term and has been defined in several different ways. Globalization indicates that the world today is more interconnected than before. According to Advered S. Herman "Globalization is the expansion across international borders of management and process. At the same time, it is a condition of facilities and economic relation which is constantly expanding and it is simultaneously changing". Globalization can be defined as the ability to provide good and service anywhere in the world using capital, technology and components from anywhere and to sell the output anywhere". Piter Jay 199630 Globalization is also a process of nation prosperity and progress as per the current trends. It involves various modern process and concepts. Admitting all these processes, concepts, terms and conditions, a lot of changes have been made in world economy under the Ay name 'Financial Reform'. Consequently, number of companies, factories, institutions and industries could enter in any part of the world. So, the economy of whole world has been opened at international level for exchange of thing, investments, capital and technology. Naturally globalization is followed by Liberalization and Privatization. And the impact of these three processes is seen in whole senior of the world.

In the present research paper these three processes in terms of advantages and disadvantages and in negative and positive aspects.is analysed. And the debate is between supporters and sceptics.

\section{Advantages and Positive Aspects of Globalization}

Now let us see some advantages and positive aspects of globalization,

Because of globalization many people in the world now live longer than before and their standard of living is far better. 
The condition of many people in the developing world, working in a factory, is far better than staying down on the farm and growing rice.

Globalization has given people in the developing countries access to Knowledge well beyond the reach of even the wealthiest in any country a century ago.

Globalization as reduced the sense of isolation with which the developing countries I

were facing from.

* Globalization has indeed brought about a sort of connectedness. And the internet is the very example of it.

* Similarly, the public pressure forced international community to forgive the debts of some of the poorest countries.

* Globalization could lead to the introduction of new technologies access to new market and creation of new industries.

* Foreign aids had benefited to million and the following are the examples of it.

1. Guerrillas in the Philippines were provided jobs by a world bank financed project as they laid down their aims.

2. Globalization has brought some irrigation projects which doubled the income of farmers.

3. Education projects have brought literacy to the rural areas.

4. AIDS projects have helped to stop spreading this deadly disease.

5. The positive aspect of globalization can be found in the growth of small-scale industries.

\section{Negative aspects and Disadvantages of Globalization}

Inspite of all the glitters and splendor of globalization, there are some darker sides of globalization.

* Globalization, Privatization and Liberalization has brought no improvement among the poor either in the Third World or in the developed countries. In the third world poverty has grown. People earning even less than a dollar in a day have increased. The actual number of people living in poverty has increased by almost 100 million.

* Globalization is also held responsible for unemployment, cultural degradation and difficulties of competition. As per the report of ILO 2004

"The lives of the educated and rich had been enriched by globalization.

The IT sector was a particular beneficially. But the benefits have not yet reached the majority and the new risks have cropped up for the losses, the socially deprived and the poor western perceptions which dominated the globe media are not alighted with local perspectives, they encouraged consumerism in the midst of extreme poverty and posed a threat to cultural and linguistic diversity."

* Due to globalization some counties specially developed have become industrial hubs covering the global demand. This has decreased entrepreneurial activities in developing countries which leads to unemployment.

* Globalization has brought the whole world so close that the whole worl has become a global village. As a result of it a collapse of share market of one country it highly affects the whole world.

* High prices, destructions of environment, rising corruption, delay in

accepting the change and the problems of social dissolution have emerged at a great scale due to globalization.

* Many projects recommended by the west and financed by the world have failed.

* Drugs companies had to lower the prizes in case of AIDS. However, with respect to the drug companies both in developed and developing world the intellectual property issue is still prevailing.

\section{CONCLUSION:}


Though there are some positive and negative sides of globalization but it is also true that one cannot keep oneself away from the process of globalization. The three main institutions IMF, WTO and World Bank which govern the process of globalization have their own limitations. So these institutions should not be held responsible for the failure of globalization. Because there are host of other institutions like UN, UNCTAD, ILO and other small banks which play a role in the international economic system. However, the process of globalization has been widely spread up and is deeply rooted in due course of time. Its impact is directly or indirectly visible everywhere in the entire world.

\section{REFERENCES:}

Manjunatha K. Impact of globalization on Indian Rural and Urban Life, IJEMR 2004

Bacchus, H \& Foerster a 2005 the effect of globalization on women in developing nations.

Joseph Stiglit, Globalization, Fragrant Aspiration. 